\title{
Liquidity Risk Analysis in Scheduled Commercial Banks
}

\author{
S. Anitha, A.R. Shanmuga Priya
}

\begin{abstract}
Liquidity risk is the bank's incompetence to meet the financial obligations on due date at rational cost and without experiencing undesirable losses. It is essential that banks should adhere to prudent liquidity risk management framework to avoid insolvency, bankruptcies and to ensure healthy and stable financial position. It also facilitates the banks to reduce the possibility of adverse situation developing. This study examines the liquidity risk management of scheduled commercial banks by applying stock approach i.e., liquidity ratios. This paper assesses the liquidity risk that the SCBs are exposed to spread over a period from 2005-2015 in order to identify effective measures to mitigate the risk. The findings from the study revealed that SCBs has better liquidity risk management framework in practice.
\end{abstract}

Index Terms: Liquidity Risk, Liquidity Risk Management,

\section{INTRODUCTION}

The banking sector plays a noteworthy part in the monetary system of India. Banks are exposed to several financial risks, nevertheless amongst them, liquidity risk is considered to be very crucial and it is directly linked to what banks do and why it fails. Liquidity risk in banking is known as the bank's scarce liquidity to pay off its financial responsibilities and may even become bankrupt. It develops a hazard, if the bank is not able to forecast the demand for loan and deposits withdrawals. It will also influence the fluctuation of interest rate and conditions of market, its ability to earn profit, and meet its long term liability. As a result, banks could not be able to sustain in the market, retain its trustworthiness, confidence of its clients, reputation and relationship with stakeholders. Banks must have a strong agenda towards risk management, in order to assess and estimate the stability and trust worthiness, to ensure a high degree of liquidity, and to minimize the liquidity associated risk level. Hence this paper has been designed with the aim to analyze the liquidity risk level of SCBs in India using stock approach.

Meaning of Liquidity Risk:

People are doing business with the banks in the belief that they could get back their funds as and when they need it. This public's trust in banks is derived from the fact that it is regulated and supervised by RBI, Government of India, on certain well established principles. In case, if any financial crisis/ economic distress condition challenges the people's confidence in banks, massive withdrawals of deposits by the investors will occur. In such a situation, if the affected banks

Revised Manuscript Received on July 05, 2019

Dr. S. Anitha, School of Management, SRM -IST Kattankulathur, Tamizhnadu, India.

A.R. Shanmuga Priya, School of Management, SRM -IST Kattankulathur, Tamizhnadu, India. Basel Committee.

are not competent to meet their financial commitments on due date, they will be exposed to liquidity risk leading to illiquidity risk and failure becomes inevitable. Further, a short fall at one bank can surpass to other banks and cause system wide disturbances. Hence, Management of liquidity risk is observed as very important for the ongoing feasibility of banks.

Meaning: Liquidity risk means the banks inability to meet its present and future financial obligations on time or inability to raise additional funds to meet the liquidity needs. This liquidity risk arises from an imbalance in the need for and the grant of funds and bank's failure to balance the gap. The funds supply derived from customer's savings, settlement of borrowings, finance from monetary system, revenue from interest and other items and disposal of banks' assets. In contrast, withdrawal of deposits, requirement of loans, outlay of interest and non-interest charges will lead to demand for funds. This liquidity gap must be handled most cautiously by the banks to contain the liquidity risk.

Liquidity Risk Measurement methods: The banks must maintain sufficient level of liquidity at all times to avoid liquidity risk. The management should always be alert for new source of liquidity risk it would be exposed to, in order to take suitable remedial measures to avoid the losses. Hence, banks must have effective system for the management of liquidity risk to identify, measure, monitor, and control its liquidity exposure. As the study focus is analysing the liquidity risk, the importance is given to liquidity risk measurement techniques in this research paper. Discussed below are some commonly used liquidity measurement techniques that may be adopted by the banking concern.

a) Stock Approach/Flow Approach:

Stock and flow method's few essential ratios, their implication and suggestive yardsticks (benchmarks) in respect of these ratios have been presented under. Banks may examine the following ratios by setting up an internal ceiling which is confirmed by the Board .The ratios under stock approach are intended for examining the liquidity threat at the point of single bank. But in this study, it has been applied to a group of banks.

1. Volatile Liabilities: (Deposits + borrowings and bills payable within one year). Letters of credit - full outstanding. Component-wise CCF of other contingent credit and commitments. Swap funds (buy/ sell) up to one year. Current deposits (CA) and Savings deposits (SA) i.e. (CASA) deposits payable in one year (as reported in structural liquidity statement) are included under volatile liabilities. Borrowings include from RBI, call, other institutions and 
refinance.

2. Temporary assets $=$ Cash + Excess $C R R$ balances with $\mathrm{RBI}+$ Balances with banks + Bills purchased/discounted up to 1 year + Investments up to one year + Swap funds (sell/ buy) up to one year.

3. Earning Assets $=$ Total assets $-($ Fixed assets + Balances in current accounts with other banks + Other assets excluding leasing + Intangible assets)

4. Core deposits $=$ All deposits (including CASA) above one year (as reported in structural liquidity statement)+ net worth.

b. Stress Testing: It is an analysis carried out under adverse economic situations designed to assess whether a bank has adequate capital to withstand the impact of adverse developments. Initially stress scenarios is designed by considering the factors such as the type of banks services, actions and exposures and then probable negative effect of these features on liquidity condition will be evaluated. The stress test result may be applied to find and measure the ability to pay off debt, profitability and solvency position.

c. Basel III Norms: Bgasel III committee prescribed two standards_Liquidity Coverage Ratio (LCR) and Net Stable Funding Ratio (NSFR) for funding liquidity. LCR indents to make sure that banks have sufficient amount of unencumbered High Quality Liquid Assets which can be transformed into cash to pay off its financial obligations for a 30 calendar day period viewpoint in a considerably cruel liquidity hassle situation and it should be greater than or equal to $100 \%$ at all the times. The LCR norms are applicable to banks from January 1, 2015 starting with a minimum $60 \%$. Further they have been given transition period of 4 years to gradually increase this ratio to $70 \%, 80 \%, 90 \%$, and $100 \%$ in the year 2016 , 2017, 2018, and 2019 respectively. The aim of NSFR stands to make certain that banks retain a constant financing profile in the ratio of their properties and off-balance sheet deeds. However, it is made applicable to banks only from the year 2018. As the duration of study covers the period from 2005 to 2015 , these two ratios were not considered in this research paper.

\section{REVIEW OF LITERATURE}

There are several studies that examined the liquidity risk measures and management in banks. But this paper is based on small literature related to how to measure liquidity risk. Abdelaziz Hakimi and Khemais Zaghdoudi have jointly undertaken a study on " Determinants of liquidity risk ", An Evidence from Tunisian Bank" in the year 2017. The researcher had used a sample of 10 Tunisian banks over the period 1980-2015 and applied panel data method. The research has used interest margin to gross assets ratio, total credit to gross deposit ratio for measuring bank performance and liquidity risk level respectively. It is found that the liquidity risk negatively impacts the bank performance.

Tariq Alzoubi carried out a study "Determinants of liquidity risk in Islamic banks" (2017) ) to assess the factors influencing liquidity threats in Islamic banks. He adopted broad model that integrates numerous factors to influence the liquidity of Islamic banks. The sample consists of forty two Islamic banks selected from fifteen countries during 2007 to 2014. He used total deposits to total assets ratio to measure liquidity risk. It is found out that there exists negative correlation between liquidity risk and cash ratio, bank size, and bank's equity, securities held by banks. On the other hand, there is a direct relationship amid liquidity threat and assets high return yielding properties.

Another study "An impact of liquidity risk on banks"-A case study of Punjab was carried out by Sadia Iqbal et al, in 2015 .The researcher investigated the impact of independent variables such as ROE, ROA, Current ratio, CAR on dependent variable liquidity risk. Cash to assets ratio is adopted to compute liquidity risk. The data of 20 banks including government and private commercial banks over a period of 20 years were used. The study found the existence of negative pressure of Capital Adequacy Ratio and Return on Equity to liquidity risk, while positive influence of Return on Asset and Current Ratio to liquidity hazard.

A relative research of Islamic and conventional banks was done by the authors Ika and Abdullah (2011) for the period 2000-07 . They used financial ratios such as cash to deposit ratio, loan to deposit ratio and liquidity ratio to measure the ability to earn profit, to pay off debt and to provide credit of the above said banking sectors. Mann-Whitney method is applied to assess the proposition. They found out that the Islamic banks has better ability to pay its liability than the conventional banks (Ika\& Abdullah, 2011).

A relative investigation of Islamic and conventional banks was conducted by Akhter, Raza, Orangzab, \&Akram,( 2011) for the period 2006-10. They used liquidity ratios such as Net loans to gross assets, liquid asset to deposit, short term fund ratio for the evaluation of Islamic and conventional banks of Pakistan during the tenure of 2006-2010. The study revealed the good performance of Islamic bank over conventional banks.

Objectives of the Study:

1. To assess SCBs liquidity position using stock approach

2. To provide suggestions for the improvement of LRM in banks.

\section{Scope of the Study:}

This study gives a detailed account of an analysis of SCBs Liquidity position during the study period 2005 to 2015 . The study has measured the liquidity position of SCBs using only stock approach.

\section{DATA AND METHODOLOGY}

Every research should have a conceptual structure for obtaining relevant data and analyzing the same in an efficient manner. Such structure or framework is known as Research Design. The research process of this study consists of the following steps:-

Research design: In this study, the researcher adopted descriptive and analytical research design. To examine the rationale, an exhaustive research on Liquidity risk levels of scheduled commercial banks are measured and interpreted. Data Sources:

The researcher has
meticulously utilized
secondary data for
Published By:
Blue Eyes Intelligence Engineering
\& Sciences Publication


International Journal of Recent Technology and Engineering (IJRTE)

ISSN: 2277-3878, Volume-8 Issue-2S4, July 2019

examination and elucidation. The necessary information were compiled from Reserve bank of India's website, published and unpublished records of the Scheduled commercial banks, trade magazines, journals, books, articles and internet sources.

\section{Sample Unit \& Size:} Banks functioning in India. This study intensively covers 20 Private sector banks, 44 Foreign sector banks,21 Nationalized banks, and 06 State Banks and its Associate Banks.

\section{Result Analysis:}

Banking institutions, hence, can determine yardsticks at low or high level depend on their experience and ability to manage liquidity threats.

The above said ratios are calculated based on the available information of Scheduled Commercial Banks and is presented below:

\section{(Volatile liabilities - Temporary Assets)/ (Earning} Assets - Temporary Asset) Ratio: This ratio portrays the level that revenue yielding properties are backed by hot money. Subsequently, as the numerator denotes short term interest penetrating money, a low and negative number suggests low risk of illiquidity.

Table 1. [ (VOLATILE LIABILITIES -TEMPORARY ASSETS)/(EARNING ASSETS-TEMPORARY ASSETS)] INDICATIVE BENCH MARK IS 40\%

\begin{tabular}{|c|c|c|c|c|c|c|}
\hline $\begin{array}{l}\text { VOL_ATILE } \\
\text { LIABIUIIIES }\end{array}$ & $\begin{array}{l}\text { TEMPORAR } \\
\text { Y ASSETS }\end{array}$ & VOL - TEM & $\begin{array}{l}\text { BARNING } \\
\text { ASSETS }\end{array}$ & $\begin{array}{l}\text { TEMPORAR } \\
\text { YASSETS }\end{array}$ & EAR-TEM & $\begin{array}{l}\text { VOL- } \\
\text { TEM/EAR- } \\
\text { TEM }\end{array}$ \\
\hline 7959706 & 4362607.51 & 3597098.49 & 21759161 & 4362607.51 & 17396553.49 & 0.20677075 \\
\hline 10583344 & 5064699.01 & 5518644.99 & 25704390 & 5064699.01 & 20639690.99 & 0.26738021 \\
\hline 13973449 & 6443495.01 & 7529953.99 & 31864599 & 6443495.01 & 25421103.99 & 0.29620877 \\
\hline 17779459 & 8962909.67 & 8816549.33 & 40140843 & 8962909.67 & 31177933.33 & 0.28278171 \\
\hline 21656520 & 10553246.29 & 11103273.71 & 48141519 & 1055324629 & 37588272.71 & 0.29539196 \\
\hline 25705010 & 11490188.81 & 14214821.19 & 56570923 & 11490188.81 & 45080734.19 & 0.3153192 \\
\hline 30280524 & 13466970.14 & 16813553.86 & 67436968 & 13466970.14 & 53969997.86 & 0.3115352 \\
\hline 36574428 & 15064941.00 & 21509487.00 & 77661054 & 15064941.00 & 62596113.00 & 0.34362337 \\
\hline 40813372 & 17286828.00 & 23526544.00 & 89795580 & 17286828.00 & 72508752.00 & 0.32446489 \\
\hline 47299178 & 19216128.36 & 28083049.64 & 102088742 & 19216128.36 & 82872613.64 & 0.33887009 \\
\hline 49655984 & 21908350.76 & 27747633.24 & 112264278 & 21908350.76 & 90355927.24 & 0.30709256 \\
\hline \multicolumn{6}{|c|}{ Mean } & .2990 \\
\hline \multicolumn{6}{|c|}{ Max } & .344 \\
\hline \multicolumn{6}{|c|}{ Min } & .207 \\
\hline \multicolumn{6}{|c|}{ Standard deviation } & .038 \\
\hline \multicolumn{6}{|c|}{ Kurtosis } & 2.85 \\
\hline
\end{tabular}

Source: Balance sheet of SCBs from RBI

It is depicted from the above table that the Scheduled Commercial Banks (SCBs) has maintained the Volatile liabilities -Temporary assets to Earning assets - Temporary Assets ratio between minimum $20 \%$ to maximum $34 \%$,i.e on an average $30 \%$ during the study period 2005 to 2015 .This trend indicates that the SCBs were able to maintain well within the bench mark ratio of $40 \%$ throughout the study period. But still, the increasing trend of this ratio i.e, from $20 \%$ in the year 2005 to $30 \%$ in the year 2015 indicates increasing risk of illiquidity. Hence it is advisable that the SCBs should try either to reduce the volatile liabilities or increase the level of earning assets.

Temporary Assets to Total Assets Ratio: This ratio measures the extent of available liquid assets. The indicative industry benchmark stipulated by the RBI is minimum $40 \%$. Higher the ratio is considered as a good indication of high liquidity but still it could affect the use of asset as regards alternative cost of maintaining liquidity.
The present study is carried out in Scheduled Commercial

Table 2. Showing Temporary Assets to Gross Assets Ratio

\begin{tabular}{|r|r|r|r|}
\hline \multirow{2}{*}{ YEAR } & $\begin{array}{l}\text { TEMPORARY } \\
\text { ASSETS }\end{array}$ & $\begin{array}{l}\text { GROSS } \\
\text { ASSETS }\end{array}$ & \multicolumn{1}{c|}{ RATIO } \\
\hline 2005 & 4362607.51 & 23555093 & 0.19 \\
\hline 2006 & 5064699.01 & 27858633 & 0.18 \\
\hline 2007 & 6443495.01 & 34599618 & 0.19 \\
\hline 2008 & 8962909.67 & 43261660 & 0.21 \\
\hline 2009 & 10553246.29 & 52386422 & 0.2 \\
\hline 2010 & 11490188.81 & 60269252 & 0.19 \\
\hline 2011 & 13466970.14 & 71833978 & 0.19 \\
\hline 2012 & 15064941 & 83208903 & 0.18 \\
\hline 2013 & 17286828 & 95899521 & 0.18 \\
\hline 2014 & 19216128.36 & 109759285 & 0.18 \\
\hline 2015 & 21908350.76 & 120341816 & 0.18 \\
\hline \multicolumn{3}{|c|}{ MEAN } & 0.188181818 \\
\hline \multicolumn{3}{|c|}{ MAX } & 0.21 \\
\hline STADNDARD DEVIATION & 0.009359664 \\
\hline
\end{tabular}

Source: Balance sheet of SCBs from RBI.

Interpretation: It is inferred from the above table that the SCBs had maintained temporary assets to total assets ratio from minimum $18 \%$ to maximum $21 \%$ during the study period. It is observed that the ratio was maintained at a very lower level comparatively to the benchmark ratio of minimum $40 \%$. It indicates that liquidity position of SCB was not maintained satisfactorily and hence the SCBs should try to improve the liquid assets.

Temporary Assets to volatile liabilities: This ratio assesses the relationship between liquid nature of investments and fluctuating liabilities. The derived result of less than one denotes the likelihood of liquidness concerns.

Table 3. Temporary Assets/ Volatile Liabilities INDICATIVE BENCH MARK IS 60\%

\begin{tabular}{|r|r|r|r|}
\hline \multirow{2}{*}{ YEAR } & $\begin{array}{l}\text { TEMPORARY } \\
\text { ASSETS }\end{array}$ & $\begin{array}{l}\text { TOTAL } \\
\text { ASSETS }\end{array}$ & \multicolumn{1}{c|}{ RATIO } \\
\hline 2005 & 4362607.51 & 23555093 & 0.19 \\
\hline 2006 & 5064699.01 & 27858633 & 0.18 \\
\hline 2007 & 6443495.01 & 34599618 & 0.19 \\
\hline 2008 & 8962909.67 & 43261660 & 0.21 \\
\hline 2009 & 10553246.29 & 52386422 & 0.2 \\
\hline 2010 & 11490188.81 & 60269252 & 0.19 \\
\hline 2011 & 13466970.14 & 71833978 & 0.19 \\
\hline 2012 & 15064941 & 83208903 & 0.18 \\
\hline 2013 & 17286828 & 95899521 & 0.18 \\
\hline 2014 & 19216128.36 & 109759285 & 0.18 \\
\hline 2015 & 21908350.76 & 120341816 & 0.18 \\
\hline \multicolumn{3}{|c|}{ MEAN } & 0.188181818 \\
\hline \multicolumn{3}{|c|}{ MAX } & 0.21 \\
\hline \multicolumn{3}{|c|}{ MIN } & 0.18 \\
\hline
\end{tabular}

Source: Balance sheet of SCBs from RBI.

Interpretation: The temporary assets to volatile liabilities ratio was maintained in the range of minimum .41 to maximum .50 during the study period 2005 to 2015 . Further the ratio was maintained at a very lower level comparatively to the benchmark ratio 1 . So it can be said that the SCBs may expose the liquidity problems as they were not able to convert $100 \%$ of their volatile liabilities into temporary assets. 
Volatile liabilities to Total Assets Ratio: It assesses the amount of balance sheet supported by fluctuating liabilities. The RBI's indicative benchmark for this ratio is maximum $60 \%$. Higher the ratio indicates the possibility of illiquidity.

Table 4. Showing Volatile Liabilities to Total Assets Ratio Indicative Bench Mark Is 60\%

\begin{tabular}{|r|r|r|r|}
\hline \multirow{2}{*}{ YEAR } & TEMPORARY & $\begin{array}{l}\text { TOTAL } \\
\text { ASSETS }\end{array}$ & \multicolumn{1}{|c|}{ RATIO } \\
\hline 2005 & 7959706 & 23555093 & 0.34 \\
\hline 2006 & 10583344 & 27858633 & 0.38 \\
\hline 2007 & 13973449 & 34599618 & 0.40 \\
\hline 2008 & 17779459 & 43261660 & 0.41 \\
\hline 2009 & 21656520 & 52386422 & 0.41 \\
\hline 2010 & 25705010 & 60269252 & 0.43 \\
\hline 2011 & 30280524 & 71833978 & 0.42 \\
\hline 2012 & 36574428 & 83208903 & 0.44 \\
\hline 2013 & 40813372 & 95899521 & 0.43 \\
\hline 2014 & 47299178 & 109759285 & 0.43 \\
\hline 2015 & 49655984 & 120341816 & 0.41 \\
\hline \multicolumn{3}{|c|}{ MEAN } & 0.409091 \\
\hline \multicolumn{3}{|c|}{ MAX } & 0.44 \\
\hline STADNDARD DEVIATION & 0.34 \\
\hline
\end{tabular}

Source: Balance sheet of SCBs from RBI.

Interpretation: It is depicted from the above table that the volatile liabilities to total assets ratio trend has increased to $41 \%$ in the year 2015 from $34 \%$ in the year 2005. It has been maintained at an average of $41 \%$ during the study period i.e., well within the limit of the stipulated benchmark of maximum $60 \%$.It indicates that only $41 \%$ of total assets has been financed by the unstable liabilities and the bank has maintained safer asset base which is less susceptible to external shocks.

Core Deposit / Total Assets Ratio: This ratio estimates the range that assets are backed by the part of constant deposit. Indicative Bench mark prescribed by RBI is Minimum 50\%. Higher the ratio indicates sound liquidity position of banks.

Table 5. Showing Core Deposits / Total Assets Ratio Indicative Bench Mark 50\%

\begin{tabular}{|r|r|r|r|}
\hline \multirow{2}{*}{ YEAR } & $\begin{array}{l}\text { TEMPORARY } \\
\text { ASSETS }\end{array}$ & $\begin{array}{l}\text { TOTAL } \\
\text { ASSETS }\end{array}$ & \multicolumn{1}{|c|}{ RATIO } \\
\hline 2005 & 12320971.81 & 23555093 & 0.52 \\
\hline 2006 & 13902127.51 & 27858633 & 0.50 \\
\hline 2007 & 16562984.48 & 34599618 & 0.48 \\
\hline 2008 & 20521068.4 & 43261660 & 0.47 \\
\hline 2009 & 24556080.85 & 52386422 & 0.47 \\
\hline 2010 & 28306556.17 & 60269252 & 0.47 \\
\hline 2011 & 34003706.61 & 71833978 & 0.47 \\
\hline 2012 & 38365058.67 & 83208903 & 0.46 \\
\hline 2013 & 46069940.35 & 95899521 & 0.48 \\
\hline 2014 & 52057539.76 & 109759285 & 0.47 \\
\hline 2015 & 59803791 & 120341816 & 0.50 \\
\hline \multicolumn{3}{|c|}{ AVERAGE } & 0.48 \\
\hline MAX & 0.52 \\
\hline \multicolumn{3}{|c|}{ MIN } & 0.46 \\
\hline STRTOSIS & 0.02 \\
\hline
\end{tabular}

Source: Balance sheet of SCBs from RBI

Interpretation: It is clear from the above table that the core deposits to total assets ratio has been maintained on an average $48 \%$ during the study period comparatively to the benchmark ratio of $50 \%$. It indicates that the scheduled commercial banks were able to maintain this benchmark with minimum variation i.e., only $2 \%$. Hence it can be said that the bank's total assets has been adequately supported by the core deposits base and the chances for facing liquidity risk are also very remote.

Limitations: This study did not consider the qualitative factors and other macro economic factors that may influence the liquidity risk position. Further it did not apply the two important ratios such as liquidity coverage ratio and Net Stable Fund ratio prescribed by the Basel-III norms .

\section{Findings:}

1. The ratio of (Volatile liabilities -Temporary assets) to (Earning assets - Temporary Assets) has been maintained by the SCBs on an average of $30 \%$ with a standard deviation of .038 during the study period 2005 to 2015. It is also observed that the SCBs have maintained this ratio well within the bench mark of $40 \%$.

2. The SCBs, Temporary Assets to Total Assets Ratio has been maintained on an average of $18.8 \%$ with a standard deviation of $.09 \%$ as against the benchmark of minimum $40 \%$. It indicates that the liquid assets were kept at very low level and thus shows that SCBs were in high risky condition.

3. Volatile liabilities to gross assets ratio (indicating assets financed by unstable liabilities ) of SCBs has been maintained at an average of $41 \%$ as against the stipulated benchmark of maximum $60 \%$, and it has reflected the bank's safer asset base .

4. The SCBs total asset has been supported by the core deposits to an extent of $48 \%$ on an average during the study period as against the benchmark ratio of $50 \%$ with only $2 \%$ variation. This indicates the remote chances of liquidity risk.

\section{Suggestions:}

- Though the SCBs has maintained the Volatile liabilities -Temporary assets to Earning assets - Temporary Assets ratio well within the benchmark of $40 \%$, the present ratio of $30 \%$ (on an Average) is also considered to be slight risk. Hence the SCBs should try to take initiation either to reduce the volatile liabilities or increase the level of earning assets.

- The SCBs should take necessary efforts to improve the level of temporary Assets proportion in the total assets so as to improve its temporary Assets to Total Assets Ratio to benchmark ratio of minimum $40 \%$ and thereby improve the liquidity condition.

\section{CONCLUSION}

This study sought to assess the liquidity risk position of SCBs in India during the study period 2005-2015. The result of analysis indicated that all the critical ratios such as (Volatile liabilities -Temporary assets) to (Earning assets -Temporary assets), Volatile liabilities to total assets ratio, core deposits to total assets ratio have been maintained well within the benchmark norms. However, it is found that they are weak in maintaining its temporary assets up to the benchmark level. Hence it is suggested that SCBs must take effort to improve its temporary 
assets level so as to have adequate level of liquidity.

Scope for Further Research: This research study can be extended further to incorporate the analysis of SCB's ability to adhere to the liquidity norms such as liquidity coverage ratio and Net Stable Fund ratio prescribed by Basel III regulations on banks. The study may also extend to cover the qualitative factors and other macro economic factors that may influence the liquidity risk position.

\section{REFERENCES}

1. Khemais Zaghdoudi and Abdelaziz Hakim, Determinants of Liquidity risk, (2017).

2. Tariq Alzoubi (2017). Determinants of liquidity risk in Islamic banks. Banks and Bank Systems, vol 12, issue 3, 142-148.

3. Sadia Iqbal et al (2015), Impact of Liquidity Risk on Banks (A Case Study of Punjab, Pakistan), http://www.iiste.org, 5 (11), 108 -116.

4. Ika and Norhayati Abdullah (2011), A comparative study of financial performance of Islamic banks and conventional banks in Indonesia, International journal of Business and social science, Vol2 (15), 199-207.

5. K.K. Siraj and P. Sudarsanan Pillai, Comparative Study on Performance of Islamic Banks and Conventional Banks in GCC region Journal of Applied Finance \& Banking, vol.2, no.3, 2012, 123-161

6. Goodhart.C(2008), liquidity risk management, Financial Stability Review , 11(6)

7. Draft guidelines on liquidity risk management and Basel III liquidity standards, RBI

8. Leonard Matz, Peter Neu, (2007), Liquidity risk measurement and management : A practitioner's guide to global best practices, John Wiley \& Sons (Asia) P.Ltd.

9. Kothari, C.R (2004), Research methodology,: Methods and Techniques, $2^{\text {nd }}$ edition, New Age International, New Delhi. 